Annals of Warsaw University of Life Sciences - SGGW

Land Reclamation No 43 (1), 2011: 87-97

(Ann. Warsaw Univ. of Life Sci. - SGGW, Land Reclam. 43 (1), 2011)

\title{
Evaluation methods of agricultural potential in rural areas including environmental function
}

\author{
RADKA VÁCHALOVÁ ${ }^{1}$, ŠTĚPÁNKA MATĚJKOVÁ ${ }^{2}$, JAN VÁCHAL ${ }^{1}$, \\ PETRA PÁRTLOVÁ ${ }^{1}$ MIROSLAV DUMBROVSKÝ ${ }^{3}$, LUBOŠ JURÍK ${ }^{4}$ \\ ${ }^{1}$ The University of South Bohemia in České Budějovice, Czech Republic. \\ ${ }^{2}$ Crop Research Institute, Praha, Czech Republic. \\ ${ }^{3}$ Brno University of Technology, Czech Republic \\ ${ }^{4}$ Slovak Agriculture University, Nitra, Slovakia
}

\begin{abstract}
Evaluation methods of agricultural potential in rural areas including environmental function. The study focuses on the environmental evaluation of land in the territory of interest by means of assessing the non-production functions. This topic is currently becoming one of the crucial moments in agriculture, water management as well as nature and landscape conservation. The soil represents an important component of the environment and influences both the quality and the quantity of produced foodstuffs due to the fact that being an abiotic factor, the soil is a part of many different natural and artificial ecosystems, affecting thus the hydrosphere, atmosphere and biosphere. The soil provides nutrients for plant growth, necessary for animal as well as human nutrition. It plays an important part in recycling and detoxification of organic materials and in the cycles of many elements. The proposed solution consists in the evaluation of the non-production soil functions in a particular territory according to chosen, usually unchangeable, soil properties on the basis of the proposed method of rating. The method is based on creating evaluation classes comprising the individual categories of soil properties. The rating expressing particular categories indicates the range of the non-production functions within the soil-ecological units in the territory of interest. The research was carried out in a territory only moderately impacted by human industrial activities. The results of the evaluation of chosen soil functions can be used in the studies focused on landscape and soil protection or in the proposals of environment-friendly management models in accordance with the rules of agricultural policy included in appropriate regulations
\end{abstract}

aimed at the protection of varied environmental components.

Key words: farmland, soil properties, environmental functions, non-production functions, method of rating.

\section{INTRODUCTION}

The importance of the soil for man is emphasized in the international document European Soil Charter (1972). Being an essential, limited and non-renewable source of food production and natural wealth of any country, the soil has to be protected concerning both its quantity and quality (Říha 1999). At present its ecological and economic evaluation is often a hot topic of theoretical studies and experimental methodologies (Novák et al. 2002). In the Czech Republic, however, such approaches of environmental economics are being developed as well as used in the decision-making processes of regional development. Due to increasing intensity of land use and growing incidence of conflicts between the economic and ecological interests it is not sufficient to evaluate the nature by means of traditional utilitarian approaches, where the main factor determining the price of 
soil is a direct profit of the evaluator (Seják et al. 1999). A more appropriate way how to express soil value can be based on the evaluation of the environmental soil functions.

The soil is viewed as a decisive surface unit of the landscape space, which determines the quality of the landscape system. The persistence and function of the soil in the landsacpe is the essential precondition of the existence, function and persistence of the agricultural landscape. Thus, the conservation of soil must be defined as a vital precondition of nature conservation, environment protection as well as the economic and social development in the territory.

Among the essential components of land resources management are correct categorization or delimitation, optimum production utilization, the assessment of risk extent and degree (predisposition to the degradation of yield parameters) in particular soil types, including soil properties monitoring. Here the basic factor is the harmonisation of the production and non-production functions in a particular area.

\section{MATERIAL AND METHODS}

The proposal of the evaluation of farmland production potential including the evaluation of its environmental functions was solved in the Zdíkov cadastral territory, which is situated in the Šumava Protected Landscape between the Vimperk Upland and the Šmava Plains. This area is characterised by preserved forest stands - mountain climax pine groves, acidophilous mountain beech stands, peat bogs and other interesting and valuable communities. The territory of interest shown in Figure 1 belongs to the Central-European territories where the negative impacts of human industrial activities are still only moderate.

The local climate is determined by the submontane character of the territory and by its broken relief with a high proportion of woodland. The average ten-year rainfall amounts to $830 \mathrm{~mm}$ per year. The annual mean temperature is $5.9^{\circ} \mathrm{C}$, the average temperature in January is $-3.8^{\circ} \mathrm{C}$, the average temperature in June is $13.5^{\circ} \mathrm{C}$. The average atmospheric moisture is around $78 \%$. The wind usually has the north direction.

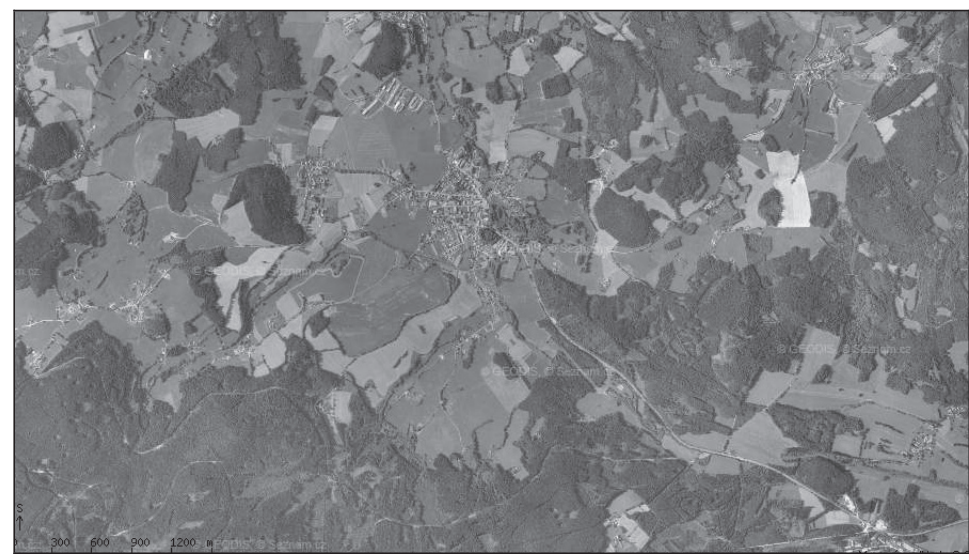

FIGURE 1. The aerial photograph of the Zdíkov cadastral territory 
The vegetation period with the daily mean temperature of above $5^{\circ} \mathrm{C}$ starts at the beginning of May. Full vegetation period with the daily mean temperature of above $10^{\circ} \mathrm{C}$ starts at the beginning of June. From the 5th October it is possible to expect the end of vegetation period with the daily mean temperature below $5^{\circ} \mathrm{C}$. Considering the fluctuations of the temperature curve, a rise in temperature can be noticed after the 15th January. This rise stops between February 14-15 , which is the period of winter monsoon. The next rise of temperature by $0.2-0.3^{\circ} \mathrm{C}$ per day appears after the $21 \mathrm{st}$ March. A following decrease in temperature comes between May 10-11. Then the temperature rises till the 8th June, with a subsequent stabilization or even a drop. The next increase in temperature comes between June 15-25. The onset of the annual peak appears between the 15th July and the 5th August when the temperature reaches the annual peak of about $14^{\circ} \mathrm{C}$. Then there is a slow decline which ends with a temporary daily increase by about $0.4^{\circ} \mathrm{C}$ during November $26-28$. This rise finishes on the 1st December and after this date the temperature falls until the 15th January (Chábera et al. 1985).
Most soils, formed on the paragneiss substrate in Liz and Albrechtec watersheds, are oligotrophic to oligo-mesotrophic brown soils. Along the streams there are mostly gleyed brown soils to brown gleys. In higher elevations there are signs of podsolization and in detritus sites appeared rankers.

$\mathrm{C}_{\text {org }}$ (organic carbon) significantly decreases with the depth as well as cationic exchange capacity and acidity, $\mathrm{pH}\left(\mathrm{H}_{2} \mathrm{O}\right)$ and $\mathrm{pH}(\mathrm{KCl})$ increase. The acidity of upper organic horizons is dominated by the presence of organic acids derived from humification processes of surface horizons. The reserve of exchangeable cations $(\mathrm{Ca}, \mathrm{K}, \mathrm{Mg})$ in the soil is low. The main buffering systems include above all the dissolution of Al secondary minerals. The role of $\mathrm{H}^{+}$exchange for $\mathrm{Ca}, \mathrm{Mg}$ and $\mathrm{K}$ is only minor in the soils where $\mathrm{pH}$ is below 5 .

The indication and quantification of farm soils production potential, including the environmental functions evaluation, was carried out in the form of consequent steps, whose system is shown in Figure 2.

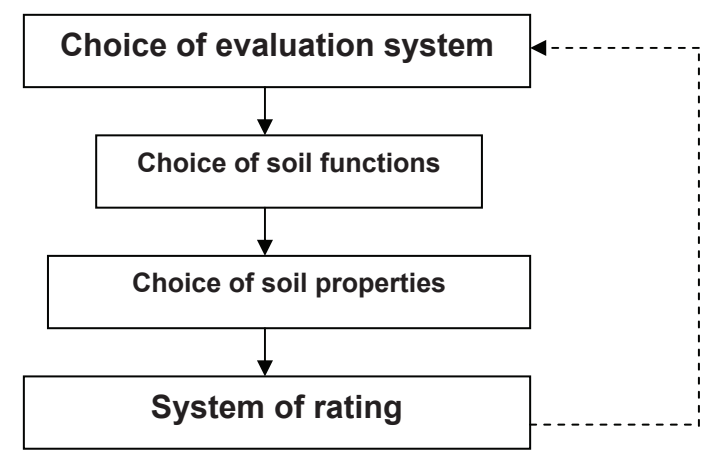

FIGURE 2. The system of soil functions rating 


\section{Choice of the evaluation system}

The precondition of a qualified choice is thorough knowledge of complex soilecological units including standardized quality assessment (BPEJ) and their precise categorization within particular aggregation groups (or varieties). The categorization comprises the following criteria: climatic characteristics of the region, soil type, grain size (texture), soil depth, erosion, skeletal type, aspect, moisture conditions, site location, site shape and situation. On this basis it is possible to classify the soils or their main soil units (HPJ) from the following viewpoints:

- Specification of cultures falling into agricultural land register;

- Blocking of the sites on the basis of soil-ecological survey;

- Classification of the soils due to the degree of hydromorphism;

- Classification of the soils according to the predisposition to soil structure and texture degradation - compaction;

- Assessment of the predisposition to erosion;

- Assessment of the predisposition to skeleton-forming texture;

- Determination and categorization of the infiltration soil capacity.

\section{Choice of soil functions for soil evaluation in the territory of interest}

The soil in the territory of interest was evaluated as an important component of the environment with a view to biomass production and the entire ecosystem function, because the territory has mostly soils with unfavourable moisture conditions which tend to get temporarily waterlogged, as well as the soils perma- nently under the influence of watercourse level, strongly acidic to podsolized. Considering the role of the soil in nourishing the plants for biomass production, its resistance to soil degradation, its importance for organic substances transformation and precipitation soaking, then the most significant environmental functions obviously become the production function and three non-production functions - the buffer function, the transformation function and the water-retention function.

\section{Choice of soil properties for soil functions evaluation}

To accomplish the assessment of the production function and the non-production soil functions we chose measurable soil properties relating to soil functions.

On the basis of two requirements for the evaluation of the production function we chose the yielding capacity, whose values were assigned to the units of the quality assessment system by Němec (2001), and which are listed in the supplement of the Government Regulation of the Ministry of Agriculture, CR. The data on farmland yielding capacity respect the economic basis of soil productivity, i.e., the value expressed as a difference between the earnings from plant production and the costs of their acquirement.

\section{Proposal of the rating system}

The rating system of soil functions evaluation was proposed to achieve the determination of the non-production functions of the qualitatively assessed units (BPEJ) within the territory of interest. It was accomplished by means of consequent steps. 
TABLE 1. Soil properties classification

\begin{tabular}{|c|c|c|c|c|}
\hline \multirow{3}{*}{\multicolumn{2}{|c|}{ Soil functions }} & \multicolumn{3}{|c|}{ Soil properties } \\
\hline & & \multirow{2}{*}{ affecting soil functions } & \multicolumn{2}{|r|}{ measurable in } \\
\hline & & & BPEJ & HPJ \\
\hline \multicolumn{2}{|c|}{ Production } & yielding capacity & yielding capacity & \\
\hline \multirow{3}{*}{ 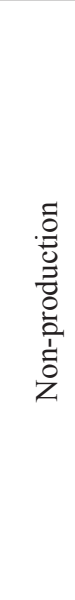 } & 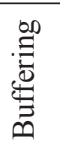 & $\begin{array}{l}\text { soil texture } \\
\text { soil depth } \\
\text { sorption properties }\end{array}$ & soil depth & $\begin{array}{l}\text { soil texture } \\
\text { cation exchange sorption capacity of } \\
\text { soil } \\
\text { degree of soil colloids base saturation }\end{array}$ \\
\hline & 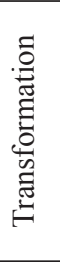 & $\begin{array}{l}\text { soil texture } \\
\text { soil microbial activity } \\
\text { soil moisture } \\
\text { soil temperature } \\
\text { soil reaction } \\
\text { soil depth } \\
\text { humus }\end{array}$ & soil depth & $\begin{array}{l}\text { soil texture } \\
\text { humus content } \\
\text { humus quality }\end{array}$ \\
\hline & 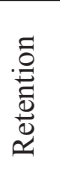 & $\begin{array}{l}\text { soil texture } \\
\text { soil depth } \\
\text { skeleton-formation } \\
\text { incline } \\
\text { soil porosity }\end{array}$ & $\begin{array}{l}\text { soil depth } \\
\text { skeleton- forma- } \\
\text { tion } \\
\text { incline }\end{array}$ & soil texture \\
\hline
\end{tabular}

The first step of the rating comprised the determination of the range of the production function of the soil-ecological units (BPEJ) in the territory on the basis of yielding capacity values. The values were used for the determination of the soil production function range which was calculated according to the formula of weighted arithmetic average. The calculated value of the soils production function was considered to be the basic value in the next step aimed at determining the value of the non-production functions of the soil in the territory of interest. The output of the first step of rating was calculated according to the following formula:

$$
\bar{x}=\frac{\sum_{i=1}^{k} x_{i} n_{i}}{\sum_{i=1}^{k} n_{i}}
$$

$\bar{x}$ - weighted arithmetic average of yielding capacity;

$x_{i}-$ yielding capacity of soil-ecological units;

$n_{i}$ - area of soil-ecological units;

$k$ - number of different variants of the character.

The second step of the rating proposal consisted in the determination of the initial value of the range of the non-production soil functions in the territory. This was calculated as a difference between the value of the range of the environmental soil functions and the initial value of the production function range. The former is represented by the number 100 , which involves the value of the production function, the buffer function, the transformation function and the retention function. The resultant initial value of the range of the non-production soil functions in the territory of interest was 
used for the determination of the range of the buffer, transformation and retention functions of the soil. The output of the second step of the rating proposal was calculated according to the following formula:

$$
\begin{aligned}
& E_{r p}=V_{r p}+V_{r m} \\
& V_{r m}=E_{r p}-V_{r p} \\
& E_{r p}=100 \\
& V_{r p}=\bar{x}
\end{aligned}
$$

$E_{r p}$ - range of the environmental soil functions;

$V_{r p}$ - initial value of the range of the production function;

$V_{r m}$ - initial value of the range of the non-production functions;

$\bar{x}$ - weighted arithmetic average of soil yielding capacity.

The third step of the rating was the determination of the buffer, transformation and retention functions of the soil units on the basis of the initial value of the non-production soil functions in the territory of interest. The initial value of the range of the non-production functions was divided into equal proportions of the initial values for the evaluation of the buffer function, transformation function and retention function so that each of the non-production functions could be viewed equally and none of them would be prioritized. The division of the initial value of the non-production functions into the same proportions was used to strengthen the objectivity of the rating. The division of the initial value of the non-production functions was calculated according to the following formula:
$H_{r m}=\frac{V_{r m}}{n}[$ rating]

$H_{r m}$ - initial value of the range of the buffer function or the range of the transformation function and the range of the retention function;

$V_{r m}$ - initial value of the range of the non-production soil functions;

$n$-number of the evaluated non-production soil functions.

Considering any particular soil function alone, the initial value of the buffering function or transformation function and retention function was divided equally among the soil characteristics which determine the importance of the soil function in the territory of interest, according to the following formula:

$B_{n}=\frac{H_{r m}}{m}$ [rating]

$B_{n}$ - basic value of the soil characteristics which relate to the buffer function or transformation function and retention function;

$H_{r m}$ - initial value of the range of the buffer function or the range of the transformation function and the range of the retention function;

$m$ - number of soil characteristics which determine the buffer function range or transformation function range and retention function range in the soil-ecological units.

The importance of the soil function was determined by particular categories of soil properties (Mašát et al. 2002), for which evaluation classes were created. The value of soil property was then divided, on the basis of the number of evaluation classes of a single soil property, according to the following formula: 
$H_{i}=\frac{B_{n}}{l}[$ rating $]$

$H_{i}$ - values assigned to the categories of soil properties which determine the range of the non-production function of the soil-ecological units;

$B_{n}$ - basic value of soil properties within the buffer function or the retention function and the transformation function;

$l$ - number of evaluation classes for the soil property which relates to the buffer function or transformation function and retention function.

The first class of the soil property evaluation was always equal to the value obtained through dividing the soil property value by the number of evaluation classes. The next classes of the evaluation were gradually assigned the value calculated as the number of the evaluation class multiplied by the value assigned to the first class of evaluation.

The fourth consequent step of the rating proposal consisted in the determination of the range of the non-production functions of the soil-ecological units and the range of the non-production functions of the soil in the territory of interest.

The range of the non-production functions of the soil-ecological units in the territory of interest was determined by adding the assigned values for the buffer function or the transformation function and the retention function according to the following formula:

$R_{m}=R_{p f}+R_{t f}+R_{r f}$

$R_{m}$ - value of the range of the non-production functions of the soil-ecological units;
$R_{p f}$ - value of the range of the buffer

function of the soil-ecological units;

$R_{f t}$ - value of the range of the transformation function of the soil-ecological units;

$R_{r f}$ - value of the range of the retention function of the soil-ecological units.

The range of the non-production soil functions was determined with the use of the formula for weighted arithmetic average on the basis of the acquired values expressing the range of the non-production functions of the soil-ecological units, whose frequency is given by their area:

$\bar{z}=\frac{\sum_{i=1}^{k} R_{m} n_{i}}{\sum_{i=1}^{k} n_{i}}$

$z$ - weighted arithmetic average of the values of the non-production soil functions range;

$R_{m}$ - value of the non-production functions range in soil-ecological units;

$n_{i}$ - area of the soil-ecological units;

$k$ - number of different variants of the character.

The obtained values of the non-production functions range and the production function range of the soil-ecological units in the territory of interest were used for elaborating the analysis of the database. The analysis comprises data on mean values, the values of aspect characteristics and variability characteristics concerning the production function range and the non-production functions range in the soil-ecological units within the territory of interest. 


\section{RESULTS}

The results expressing the range of the non-production functions of the soil-ecological units were processed according to the method described in the chapter dealing with the proposal of soil functions rating within the territory of interest. rating of the soils in the Czech Republic is 46.2 points. According to given values it is obvious that yielding capacity in the territory of interest is approximately 2.5 times lower.

\section{The calculation of the total farmland production potential consists of two parts (Váchalová 2004):}

TABLE 2. Descriptive statistical overview of the main soil units (HPJ) in the territory

\begin{tabular}{|l|l|c|c|c|c|r|}
\hline \multicolumn{1}{|c|}{ Soil type } & \multicolumn{1}{|c|}{$\begin{array}{c}\text { HPJ } \\
\text { (Main soil units) }\end{array}$} & Mean value & Median & Modus & $\begin{array}{c}\text { Standard } \\
\text { deviation }\end{array}$ & Variance \\
\hline Cambisol & $34,36,37,39,40$ & 16.62 & 16.32 & 16.49 & 4.41 & 22.85 \\
\hline Pseudogley & 50 & 23.50 & 23.31 & 23.31 & 3.05 & 9.34 \\
\hline Fluvisol & 56,58 & 33.17 & 32.86 & 31.53 & 1.97 & 3.39 \\
\hline Gley & $64,65,67-77$ & 16.79 & 14.21 & 11.37 & 7.37 & 21.60 \\
\hline
\end{tabular}

Frequency-related yielding capacity values of the soil-ecological units are shown in Figure 3 (including cumulative relative frequency).

Figure 4 shows the range of the production function of the main soil units in the territory of interest, the average range of the production function in the territory , and the average yielding capacity for the Czech Republic as published by Novák et al. (1999). The average yielding capacity
1. Determination of farmland production potential $\mathrm{PP}_{\mathrm{zp}}$.

2. Determination of farmland environmental (non-production) potential $\mathrm{EP}_{\mathrm{zp}}$.

The calculation of the production potential $\mathrm{PP}_{\mathrm{zp}}$ is accomplished by the formula for the evaluation of soil-climatic properties by means of the method of rating $-\mathrm{BH}_{\mathrm{BPEJ}}$ (Němec 2001). The result is so called initial production poten-

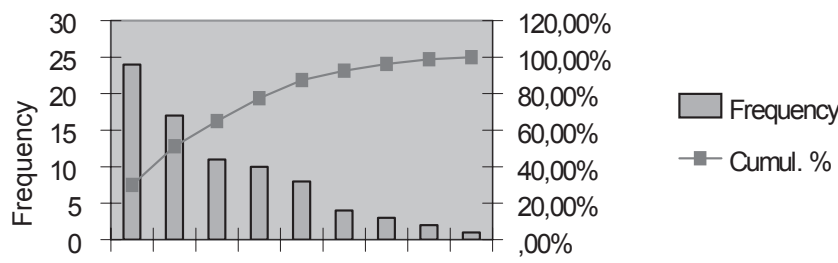

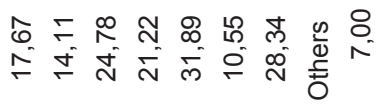

Classes

FIGURE 3. Histogram of yielding capacity classes frequency of the soil-ecological units in the territory of interest 


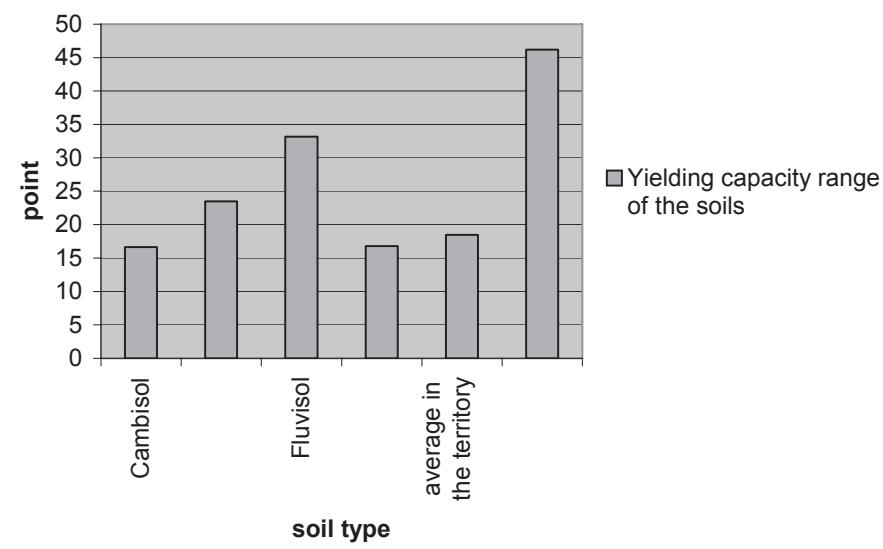

FIGURE 4. Yielding capacity range of the soils in the territory of interest and average yielding capacity of the soils in the CR (Matějková 2006)

tial $\mathrm{VP}_{\mathrm{p}}$, which is subsequently adjusted with the use of newly proposed deficit parameters, the appropriate values being expressed in points.

The formula for the calculation of farmland production potential $\left(\mathrm{PP}_{\mathrm{zp}}\right)$

$\mathrm{PP}_{\mathrm{zp}}=\left[\mathrm{BH}_{\mathrm{BPEJ}}=\left(\mathrm{B}_{\mathrm{HPJ}}+\mathrm{B}_{\mathrm{Z}}+\mathrm{B}_{\mathrm{SE}}+\right.\right.$

$\left.\left.+\mathrm{B}_{\mathrm{KH}}\right) \cdot \mathrm{K}_{\mathrm{KR}}\right]$

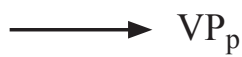

$\mathrm{PP}_{\mathrm{zp}}=\mathrm{VP}_{\mathrm{p}} \cdot \mathrm{O}_{\mathrm{DfP}}$

where:

$\mathrm{PP}_{\mathrm{zp}}$ - farmland production potential;

$\mathrm{VP}_{\mathrm{p}}$ - initial production potential;

$\mathrm{O}_{\mathrm{DfP}}$ - corrective deficit parameter;

$\mathrm{B}_{\mathrm{HPJ}}-$ points for the main unit, $1-50$ points;

$\mathrm{B}_{\mathrm{Z}}$ - points for granularity, 1-25 points;

$\mathrm{B}_{\mathrm{SE}}$ - points for incline (S) and aspect

(E), 0-10 points;

$\mathrm{B}_{\mathrm{KH}}-$ points for stoniness $\mathrm{K}$ ) and soil depth $(\mathrm{H}), 0-15$ points;

$\mathrm{K}_{\mathrm{KR}}-$ coefficient for climatic region, 0.60-1.00

Functional criteria of the complex evaluation system were chosen to involve the following aspects:
- production;

- soil resistance to particular negative and degradation agents:

- acidification and debasification,

- contamination and intoxication with the worst pollutants,

- water and wind erosion,

- water regime of soils;

- condition and loss of organic matter;

- degradation or loss of soil structure. To achieve a complex evaluation of the farmland, the following functional criteria were chosen:

1. Production potential.

2. Buffering capacity.

3. Resistance to contamination and intoxication.

4. Potential predisposition to wind erosion.

5. Potential predisposition to water erosion.

6. Water regime of soils.

7. Soil structure and structure-forming processes.

8. Humus content and quality. 


\section{DISCUSSION}

\section{AND CONCLUSIONS}

The new proposal is considered to be beneficial mainly for the following reasons:

- The methodology integrates the entire landscape potential with the production potential of farmland;

- Compared with the current methodologies, the proposed approach is more accurate and displays a better information capacity as well as distinction capacity;

- After its finalization the method can become a relevant basis for the state policy of subsidies and grants allocation as well as the decision-making policy concerning the EU funds allocation, namely the Structural Funds;

- The utilization of the method can be also seen in the sphere of the environment and landscape forming and protection, especially the delimitation of protected landscapes and their management rules declared for particular zones;

- The proposed procedure and its outputs can become an important basis for the creation of development plans;

- Practical outputs for the territories with agricultural land use can help otimize both the structure and production in local business, including the elements of multifunctional management.

To objectively evaluate the newly designed methodology and the computational procedure, the authors of the study chose a marginal area in the Šmava Mts. - the area around the town of Zdíkov. The necessary inputs are comparable with those in the current procedure, both as to the necessary technical equipment and the need of time for obtaining the results which, however, display a better quality and exploitation value.

The obtained data can be used even beyond the mentioned scope - e.g., for soil properties monitoring, amelioration of land resources, nature resources conservation and landscape cultivation, designing land adjustment projects, and in the field of the policy of subsidizing from the point of view of setting priorities and making the given process more objective.

The assessment of the proportion of particular soil functions, including the assessment of risk, makes it possible to use farmland in accordance with its natural potential. A better insight into these regularities was the main scientific attribute of the proposed solution.

\section{Acknowledgement}

The research presented here was supported by the grant of the Academy of Science of the Czech Republic No. 6007665806 and research grant of Ministry of Agriculture of the Czech Republic NAZV QH 92298.

\section{REFERENCES}

CHÁBERA S., KOL A. 1985: Jihočeská vlastivěda Neživá príroda. (South Bohemia Homeland Study; Inanimate nature) 1st ed. České Budějovice: published by Jihočeské nakladatelství.

Council of Europe 1972: European Soil Chapter.

MAŠÁT K., KOL A. 2002: Metodika vymezování a mapování bonitovaných půdně ekologických jednotek (Method of deli- 
neating and mapping soil-ecological units with quality assessment), 3rd ed. Praha: published by Výzkumný ústav meliorací a ochrany půdy, p. 113.

MATĚJKOVA Š S. 2006: Návrh indikace a kvantifikace mimoprodukčních funkcí v zemědělsky využívané krajině (Proposal of non-production functions indication and quantification in farmland). Jihočeské univerzita, Zemědělská fakulta.

NĚMEC J. 2001: Evaluation and land appreciation in the Czech Republic. Published by Výzkumný ústav zemědělské ekonomiky Praha, p. 257.

NĚMEČEK J., KOL A. 2001: Taxonomický klasifikační systém půd České republiky (Taxonomic classification system of the soils in the CR). 1st ed. Praha: published by ČZU with VÚMOP, p. 78.

NOVÁK P., KOL A. 1999: Situační a výhledová zpráva Půda (Report on situation and perspectives: Soil). 3. ed. Praha: MZe České republiky, p. 58.

NOVÁK P., KOL A., 2002: Stanovení kritérií a potenciálů kvality půdy $\mathrm{z}$ hlediska jejich významu pro plnění jednotlivých produkčních a mimoprodukčních funkcí půdy.(Determining criteria and soil quality potentials with respect to their importance for fulfilment of individual production and non-production soil functions) Uživatelský výstup O1 projektu QD 1300, Praha: VÚMOP Praha, p. 30.

ŘíHA J. 1999. Oceňování pozemků pomocí ekologické hodnoty půdy (Site valuation using the ecological value of soil). Ochrana prírody, vol. 54, no 4, 1999. p. 120-122.

SEJÁK J., KOL A. 1999: Oceňování pozemků a prírodních zdrojů (Valuation of sites and natural resources). 1st ed. Praha: published by Grada Publishing, p. 256.

VÁCHALOVÁ R. 2004: Monitoring hodnocení produkčního potenciálu zemědělských půd $\mathrm{v}$ procesu tvorby GIS (Monitoring and evaluation of farmland production potential in GIS forming). Jihočeské univerzita, Zemědělská fakulta.
Streszczenie: Metoda oceny potencjału produkcyjnego obszarów rolniczych z uwzględnieniem ich funkcji przyrodniczych. Praca dotyczy metodyki oceny produkcyjnego potencjału gleb z uwzględnieniem nieprodukcyjnych funkcji gleby. Gleba jest podstawowym komponentem przyrody i wpływa na jakość i ilość produkowanej żywności. Jednocześnie jest abiotycznym składnikiem różnych naturalnych i sztucznych ekosystemów, i wpływa na hydrosferę, atmosferę i biosferę. Gleba jest zarówno zbiornikiem składników potrzebnych dla rozwoju roślin, jak również jest miejscem recyrklulacji i detoksykacji zanieczyszczeń organicznych i innych związków mineralnych. Proponowana metodyka polega na wycenie punktowej nieprodukcyjnych funkcji gleby. Istota tej metody polega na przyporządkowaniu wartości punktów w zależności od kategorii i charakterystyki gleby. Na podstawie liczby punktów były określone stopnie środowiskowych funkcji ekologicznych jednostek gleby na obszarze badań. Badania prowadzono w miejscach, w których negatywne oddziaływanie przemysłu jest minimalne. Wyniki badań służyć będą do opracowania koncepcji ochrony gleb i krajobrazu lub mogą być wykorzystane w modelach symulacyjnych dla prognozowania sposobów gospodarowania zasobami glebowymi, przyjaznymi dla środowiska. Sposoby te mogą być wykorzystane do opracowania dobrych praktyk rolniczczych uwzględniających przede wszystkim środowiskowe funkcje gleby.

Słowa kluczowe: grunty rolne, właściwości gleby, funkcje środowiskowe, nieprodukcyjna funkcja gleby, metoda wskaźnikowa oceny.

MS. received May 2012
Authors' address:
Radka Váchalová
The University of South Bohemia
37005 České Budějovice,
Studentska 13
Czech Republic
e-mail: r.vachalova@seznam.cz 